В.Ф. Басанець, кандидат політичних наук;

Н.Д. Колотова, О.В. Хардікова

ВДА імені Євгенія Березняка

\title{
ІНДИВІДУАЛІЗАЦІЯ НАВЧАННЯ ЛЕКСИЧНОГО МАТЕРІАЛУ СЛУХАЧІВ ВВНЗ НА ЗАНЯТТЯХ 3 АНГЛІЙСЬКОЇ МОВИ
}

У статті піднімається питання індивідуалізації навчання іншомовного лексичного матеріалу на практичних заняттях з англійської мови, визначено прийоми та методи індивідуалізачії навчання англомовного лексичного матеріалу слухачів ВВНЗ. Одним $з$ реальних чинників, які здатні вирішити проблеми у формуванні особистості, $\epsilon$ індивідуалізачія навчального проиесу. Такий метод неодноразово застосовувався при реалізації ідей особистісно-орієнтованої освіти, щуо значно впливає на прочес підвищення ефективності навчання. Підкреслюється важливість використання мультимедійних засобів у прочесі навчання і роль індивідуальної та колективної проектної роботи.

Ключові слова: індивідуалізачія; проектна робота; лексична одиниия; мовленнєві навички; вміння.

Постановка проблеми. Сучасний рівень розвитку українського суспільства висуває нові, все більш високі вимоги до підготовки фахівців, в тому числі й військових. Водночас особливої важливості набуває питання про володіння іноземною мовою, а отже зростає і відповідальність вищого військового навчального закладу (ВВНЗ) у підготовці висококваліфікованих спеціалістів. Програма з іноземних мов ВВНЗ передбачає у тих, хто навчається, розвиток мовної компетенції, під якої розуміють уміння користуватися лінгвістичною системою 3 метою спілкування відповідно до ситуації. Підготовка з іноземної мови викликає потребу оптимізації системи викладання цієї навчальної дисципліни. В тої же час на педагогічну діяльність суттєво впливає сучасний соціальний стан в країні який потребує якісно нового, студентоцентричного підходу до навчального процесу. Одним 3 реальних чинників, що дає змогу вирішити подібні проблеми у розвитку особистості, $є$ індивідуалізація навчального процесу. Такий метод неодноразово застосовувався при реалізації ідей особистісно-орієнтованої освіти, що значно впливає на процес підвищення ефективності навчання.

Аналіз досліджень i публікацій. Завдання науково-педагогічних працівників (НПП) полягає в тому, щоб максимально розкрити талант слухача та підготувати його до майбутньої професійної діяльності. Проблема індивідуалізації навчання на сьогоднішній день $\epsilon$ однією 3 найбільш популярних у сучасній педагогіці $[4 ; 7 ; 8 ; 14]$. Проте, методи та прийоми індивідуалізації навчання лексичного матеріалу у вищих навчальних закладах (ВНЗ) у тому числі і Воєнно-дипломатичній академії (ВДА), є недостатньо вивченими $[2 ; 3 ; 6 ; 9 ; 15]$.

Метою статті є визначення прийомів та методів індивідуалізації навчання англомовного лексичного матеріалу слухачів ВДА.

Виклад основного матеріалу. Як відомо, індивідуалізація навчання $\epsilon$ організація навчального процесу з урахуванням індивідуальних особливостей тих, хто навчається; вона дозволяє створювати оптимальні умови для реалізації потенційних можливостей кожної особи. Під індивідуалізацією прийнято розуміти створення таких умов навчання та підготовки слухача, за яких 
найбільш повно та глибоко розкриється його особистість [10]. Найкраще особистість слухача може розкритися при виконанні самостійної роботи, пов'язаної з пошуком, систематизацією чи отриманням позитивних емоцій під час виконання завдання [9; 12]. У такий спосіб слухач отримує можливість розкрити свій потенціал, виконуючи завдання у відповідності до своїх умінь та навичок, покращити та поглибити свої знання, підвищити свою самооцінку, залишатися вмотивованим та зберігати інтерес до предмету навчання [10; 15].

На заняттях 3 англійської мови навчання іншомовного лексичного матеріалу якнайкраще сприяє забезпеченню принципу індивідуалізації. Необхідність засвоєння лексики в межах програми, яка $\epsilon$ різноманітною за своєю тематикою та спрямуванням, дає широкі можливості викладачу щодо індивідуального підходу до кожного окремого слухача. Так, на заняттях можлива організація умовно-комунікативних та комунікативних вправ [8], які би враховували індивідуальні особливості кожного слухача у фронтальному, індивідуальному чи груповому режимах. Наразі, можливості викладача розширюються із впровадженням у процес навчання нових комп'ютерних програм та джерел. Поєднання технічних засобів навчання та електронних джерел разом із створенням відповідного навчального середовища на заняттях 3 англійської мови дає найкращі результати.

В сучасній методиці навчання іноземних мов види індивідуалізації визначаються відповідно до характеру підструктур психологічної структури індивідуальності слухача, зважаючи на те, що кожна 3 них здійснює значний вплив на рівень володіння слухачем іноземною мовою.

Слід зауважити, що для ефективного впровадження індивідуалізації на заняттях з іноземної мови розрізняють чотири підструктури психологічної схеми індивідуальності [11]:

1) спрямованості (бажання, інтереси, світогляд, нахили, мотиви, переконання);

2) соціального досвіду (навички, вміння, знання, звички);

3) форм відображення (психічні процеси та емоційно-вольові якості особистості, що розвиваються і вдосконалюються у різних видах діяльності);

4) біологічних властивостей (психологічні особливості особистості, що зумовлюють індивідуальний стан його діяльності: працездатність, темп роботи).

Підструктура спрямованості об'єднує схильності, бажання, інтереси, ідеали, світогляд, переконання та мотиви. У процесі оволодіння іншомовною мовленнєвою діяльністю найбільш вагомим виступає мотиваційний фактор. У слухачів проявляються різні види мотивації, головними 3 яких виступають «зовнішня» або широка соціальна мотивація і «внутрішня», зумовлена самою навчальною діяльністю.

Найвищий інтерес та успішність при вивченні іноземної мови досягаються при співвідношенні зовнішньої і внутрішньої мотивації як 70\% до 30\% [5]. Отже, врахування відмінностей у мотиваційній сфері слухачів i може здійснюватись за допомогою «мотивуючої» індивідуалізації.

Підструктура соціального досвіду охоплює знання, вміння, навички, звички. І.К.Платонов називає цю підструктуру індивідуальною культурою або підготовленістю. При навчанні іноземних мов провідним компонентом 
виступає рівень сформованості іншомовних навичок і вмінь, який може бути підвищений за допомогою лише регулювання режимів навчання, у зв'язку з чим відповідний вид індивідуалізації називається «регулюючою» індивідуалізацією. Регулююча індивідуалізація спрямована на врахування викладачем реального рівня володіння слухачем іншомовним мовленням на кожному 3 етапів навчального процесу. Вона передбачає, з одного боку, можливість тимчасового спрощення і часткового варіювання завдань за умови одержання необхідного кінцевого «продукту» згідно з вимогами програми, а з другого - розширення та ускладнення програмних вимог для добре підготовлених i зацікавлених іноземною мовою слухачів.

До третьої підструктури входять психічні процеси та емоційно-вольові якості особистості, які розвиваються і вдосконалюються в різних видах діяльності. Для якісного і швидкого оволодіння іншомовним мовленням слід мати добре розвинені фонематичний слух і слухову пам'ять, достатній безпосередній обсяг пам'яті, гнучке словесно-логічне мислення i високу емоційну стійкість. В окремих слухачів ці процеси та якості слід розвивати цілеспрямовано на матеріалі іноземної мови. Відповідно цей вид індивідуалізації називається «розвиваючою» індивідуалізацією. Розвиваюча індивідуалізація дозволяє, по-перше, забезпечити в навчальному процесі опору на реальний рівень функціонування психічних процесів, а по-друге, реалізувати цілеспрямований розвиток слабо функціонуючих психічних процесів за допомогою спеціально підібраних серій завдань на матеріалі іноземної мови.

Четверта підструктура охоплює психологічні особливості індивіда, що зумовлюють індивідуальний стиль його діяльності.

В поняття індивідуальний стиль навчальної діяльності входять: темп роботи, працездатність та особливості володіння способами і прийомами навчальної роботи на основі наявних знань, навичок та вмінь. Однак він виробляється і вдосконалюється, якщо людина активно шукає прийоми та способи, які допомагають їй згідно 3 іiі темпераментом досягати кращих результатів. Одне із завдань викладача іноземної мови полягає у наданні допомоги слухачу у формуванні індивідуального стилю оволодіння іншомовною діяльністю. Тому цей вид індивідуалізації названо «формуючою» індивідуалізацією. Формуюча індивідуалізація має сприяти формуванню у слухачів індивідуального стилю оволодіння іншомовною мовленнєвою діяльністю 3 урахуванням і в опорі на індивідуальні особливості нервової системи слухача та стиль діяльності, який уже склався.

Вищеназвані види індивідуалізації слід реалізувати у навчальному процесі в комплексі, оскільки й індивідуальні особливості людини мають формуватися комплексно. Крім того, практична реалізація вищезгаданих видів індивідуалізації пов'язана 3 необхідністю вивчення індивідуальнопсихологічних особливостей слухачів.

Практичний досвід показує, що серед впроваджуваних методів і прийомів індивідуалізації навчання найбільш результативним $є$ залучення слухачів до проектної роботи. Проектна робота - це такий вид самостійної діяльності слухача, коли відбувається максимальна активізація умінь та навичок, отриманих ним на заняттях, а кінцевий результат $є$ синтезом пошукової, 
аналітичної або узагальнюючої діяльності, а також власної творчості слухача [1; 13]. Така проектна робота може відбуватися як у групах, так і індивідуально.

Одним із експериментальних проектних завдань, яке проводилося на занятті з англійської мови, було завдання зі створення слухачами презентації на задану тему. Так, слухаючи мали вибрати одну із тем презентації «Збройні сили країн, мова яких вивчається», «Історія країн, мова яких вивчається», «Операції HATO з підтримання миру» тощо й в одній із таких програм як Power Point або Windows Live Movie Maker створити відео, яке б ілюструвало цей матеріал, та озвучити його. Практичними цілями такого завдання, які ставилися перед слухачами, були розвиток навичок підготовленого монологічного мовлення й удосконалення дій слухачів із засвоюваними лексичними одиницями, а саме їх ситуативне вживання. Освітньою метою було розширення та поглиблення знань слухачів про специфіку підготовки збройних сил та спеціальних підрозділів країн, мова яких вивчається, оперативного обладнання території, історія та звичаї населення країн, мова яких вивчається. Розвиваючих цілей також було кілька. Особлива увага приділялася розвитку здатності мовного самоконтролю. У зв'язку з тим, що кожен слухач мав записати свій голос, а саме завдання мало бути представлене на занятті перед іншими слухачами, передбачалося, що кожен слухач більш ретельно і сумлінно підійде до виконання завдання та намагатиметься уникати помилок або виправляти їх, прослухавши себе.

Ті ж слухачі, що підготувалися, проявили себе як креативні й цікаві особистості. Вони підібрали ілюстрації до обраної тематики в Інтернеті, а деякі помістили i власні розробки на слайдах. Також, варто відмітити, що необхідність запису власного голосу на цифровий носій потребувала від тих, хто навчається, записувати та перезаписувати власний текст по кілька разів, аби зменшити кількість помилок і неточностей. У результаті цього грамотність монологічних висловлювань покращилася приблизно на $30 \%$. Хоча такі завдання і потребують від слухачів певного часу на підготовку, вони $\epsilon$ ефективними. Індивідуальність слухача, його творчий та пошуковий потенціал при підготовці до таких занять розкриваються повніше, крім того, ми можемо говорити і про те, що слухач готується таким чином до виконання завдань за призначенням, тобто вже матиме навички і вміння розробки презентацій, представлення потрібної інформації і події, що робитиме такого слухача більш підготовленим до вимог сучасності. Окрім цього, викладач досить успішно досягає практичних цілей, які ставить перед собою на кожному окремому занятті. Лексична одиниця, повторена слухачем під час підготовки такого креативного завдання, а також прослухана в колективі на занятті, як показує практика, стійкіше тримається в активному словнику слухача, ніж та, що була вивчена в результаті виконання некомунікативних завдань.

Іншим варіантом проектної роботи є робота у групах. Під час групової роботи на заняттях 3 іноземних мов слухачі розвивають такі навички, як слухати співрозмовника, аргументувати свої погляди, пропозиції, аналізувати й узагальнювати інформацію, робити висновки. Важливим аспектом, який викладач має брати до уваги, є те, що така робота допомагає не лише в автоматизації дій слухачів із лексичними одиницями, що вивчаються, але й розвитку комунікативних здібностей слухачів та вміння працювати та 
взаємодіяти з партнером. Комунікативні здібності $є$ одним із об'єктів, які орієнтують викладача в індивідуальному підході до слухачів які, відрізняючись якістю знань, вміннями, навичками потребують того, щоб всі ці відмінності були помічені, усвідомлені викладачем та стали б керівництвом до дії для нього.

Контрольний зріз знань слухачів після проведеного завдання також показав, що засвоєння лексичних одиниць у більшості слухачів було на 15 \% кращим. Окрім досягнення поставленої практичної мети, слід відмітити той факт, що майбутні фахівці ВДА також готуються до подальшої фахової діяльності, яка іноді передбачає виконання поставлених задач у групах та отримують навички презентації добутої інформації перед аудиторією. На останньому році навчання є доцільним залучати слухачів до перекладацької діяльності, коли, наприклад, один із слухачів групи без підготовки перекладає своїх колег, які роблять презентацію.

Висновок. Реалізація чотирьох видів індивідуалізації у комплексі сприяє найповнішому забезпеченню практичних, виховних, фахових i розвиваючих цілей навчання іншомовної мовленнєвої діяльності. Досвід використання проектної роботи на практичних заняттях з англійської мови відіграє важливу роль не лише для розвитку та вдосконалення лексичних навичок та вмінь слухачів, але й при правильному підході, дозволяє підготувати їх до майбутньої фахової діяльності та навчити взаємодіяти у колективі.

Перспективою подальшого наукового дослідження с розробка та впровадження проектної роботи 3 метою розвитку інших комунікативних навичок та вмінь слухачів, а також залучення статистичних методів для визначення ефективності використання проектної роботи на практичних заняттях з англійської мови у ВВНЗ.

\section{ЛІТЕРАТУРА}

1. Арванітопуло Е. Г. Проектна методика навчання англійської мови на старшому ступені ліцею: автореф. дис. на здобуття наук. ступеня канд. пед. наук: спец. 13.00 .02 / Е.Г. Арванітопуло. - К., 2006. - 22 с.

2. Вінніченко Н. А. Вплив проблемно-комунікативного курсу навчання англійської мови на психологічні характеристики тих, хто навчається: автореф. дис. на здобуття наук. ступеня канд. психол. наук: 19.00.07. / Н. А. Вінніченко. - Х., 1995. - 18 с.

3. Сфімова O. М. Оволодіння іноземною мовою в умовах вищого військового навчального закладу / О. М. Єфімова. - К.:ВІКНУ, 2007. - 451 с.

4. Коношевський $О$. Л. Індивідуалізація самостійної роботи майбутніх учителів математики засобами мультимедіа: дис.... канд. пед. наук: 13.00 .04 / О. Л. Коношевський. Вінниця, 2007. - 235 с.

5. Кузовлев В. П. Индивидуализация обучения иноязычной речевой деятельности как средство создания коммуникативной мотивации: автореф. дис. на здобуття наук. ступеня канд. пед. наук: спец. 13.00.02 / В. П. Кузовлев. - . М., 1982. - 16 с.

6. Мамчур К. В. Проблеми іншомовного навчання аудіюванню військових фахівців / К.В. Мамчур. - К.:ВІКНУ, 2007. - 451 с.

7. Мелікова С. О. Індивідуалізація професійно орієнтованого навчання іноземних мов студентів немовних спеціальностей у вищих педагогічних закладах: дис.... канд. пед. наук: 13.00.09 / С. О. Мелікова. - Кривий Ріг, 2008. - 216 с.

8. Ніколаєва С. Ю., Бігич О. Б. Методика навчання іноземних мов у середніх навчальних закладах: [наук.-метод. посіб.] / С. Ю. Ніколаєва, О. Б. Бігич. - К.: Ленвіт, 1999. - 320 с. 
9. Опрышко A. A. Индивидуализация обучения средствами новых информационных технологий (На примере обучения иностранному языку): дис. ... канд. пед. наук: 13.00.01 / А. А. Опрышко. - Таганрог, 2004. - 136 с.

10. Педагогічний словник. - [Електронний ресурс]. - Режим доступу до сайта: http://encdic.com/pedagogics. - Назва з екрана.

11. Платонов К .К. Структура и развитие личности / К.К.Платонов. - М.: Наука,1986. - 254 с.

12. Собина T. А. Индивидуализация обучения и развитие способностей учащихся // Фестиваль педагогических идей "Открытый урок" [Електронний ресурс]. - Режим доступу до сайта: http://festival.1september.ru/articles/310765. - Назва з екрана.

13. Тітова B. B. Модульно-проектна методика навчання англійської мови студентів вищих технічних закладів освіти: автореф. дис. на здобуття наук. ступеня канд. пед. наук: спец. 13.00.02 / В. В. Тітова. - К., 2001. - 19 с.

14. Чернякова И. Л. Индивидуализация обучения как инновационная идея современной педагогики: историко-культурный контекст // Инновации вобразовании: Вестник Нижегородского университета им. Н.И. Лобачевского. - Нижний Новгород, 2009. - № 4. - С. 18-23.

15. Шевченко С. П. Індивідуалізація навчання у вищій школі (на прикладі викладання іноземних мов) // Українська наука в мережі Інтернет: Педагогіка [Електронний ресурс]. Режим доступу до сайта: http://intkonf.org. - Назва з екрана.

В.Ф. Басанец, кандидат политических наук;

Н.Д. Колотова, О.В. Хардикова

Воєнно-дипломатическая академия

имени Евгения Березняка

\section{ИНДИВИДУАЛИЗАЦИЯ ОБУЧЕНИЯ ЛЕКСИЧЕСКОМУ МАТЕРИАЛУ}

СЛУШАТЕЛЕЙ ВВУЗ НА ЗАНЯТИЯХ АНГЛИЙСКОГО ЯЗЫКА

B статье рассматривается индивидуализации обучения иноязычному лексическому материалу на практических занятиях по аналийскому языку, определены приемы и методы индивидуализации обучения англоязычному лексическому материалу слушателей ВВУЗ. Подчеркивается важность использования мультимедийных средств в прочессе обучения и роль индивидуальной и коллективной проектной работыл. Одним из реальных факторов, которые способны решить проблемь в развитии личности, является индивидуализация учебного прочесса. Такой метод неоднократно применялся при реализации идей личностноориентированного образования, что значительно влияет на процесс повышения эфрективности обучения.

Ключевые слова: индивидуализация; проектная работа; лексическая единица; речевые навыки; умения.

V.Basanets, Ph. D. in Political Science;

N.Kolotova, O. Khardikova

Military-Diplomatic Academy

named after Yevheniy Berezniak

\section{INDIVIDUALIZATION OF VOCABULARY ACQUISITION BY STUDENT}

OFFICERS IN LANGUAGE CLASSROOM

The article deals with individualization of foreign vocabulary acquisition during practical English classes; techniques and methods for individualization of learning foreign vocabulary are determined for student officers of Military Diplomatic Academy. The importance of using multimedia for learning and the role of individual and collective project work is highlighted. One of the real factors that can solve multiple problems in personality development is the individualization of the educational process. This method is often used for implemention of personality-oriented education ideas, which greatly facilitates the efficiency of the training process.

Keywords: individualization; project work; lexical unit; language skills; ability. 